INTERNATIONAL JOURNAL OF RESEARCHES IN BIOSCIENCES, AGRICULTURE AND TECHNOLOGY

(C) VISHWASHANTI MULTIPURPOSE SOCIETY (Global Peace Multipurpose Society) R. No. MH-659/13(N) www.vmsindia.org

\title{
PRODUCTION AND PARTIAL PURIFICATION OF PECTINASE BY FUNGAL STRAINS GROWN ON ORANGE PEEL
}

\author{
V. G. Meshram \\ University Deptt. of Biochemistry,RTM Nagpur University,Nagpur. \\ vgmesh@gmail.com
}

\begin{abstract}
Abstract The peel of citrus fruits contains a large percentage of pectin which can be a good substrate for pectinolytic microorganisms. These microbes secrete large amount of extracellular enzymes to degrade the cell wall of substrates. The current study was conducted for the production and characterization of pectinase from fungal strains using citrus fruits peel as a substrate. The optimum pectinase production was analyzed from pectinase activity assay. A. niger,A. flavus and A.fumigatus, showed maximum production at 6 th day,and A. oryzae, at 4 th day. The optimum temperature for pectinase production by $\mathrm{A}$. niger and $\mathrm{A}$. oryzae was found to be $35 \hat{\mathrm{A}}^{\circ} \mathrm{C}$ and for $\mathrm{A}$. flavus and $\mathrm{A}$. fumigates was found to be $40 \hat{A}^{\circ} \mathrm{C}$. Pectinase showed optimum $\mathrm{pH}$ in the range of $\mathrm{pH}$ 4.5-5.0. Pectinase was purified by the addition of $60 \%$ of ammonium sulfate precipitation and dialysis and showed various fold increase in pectinase activity.
\end{abstract}

Keywords: Citrus fruits, pectinase, A. niger, A. flavus, A. oryzae , A.fumigatus.

\section{Introduction:}

Citrus fruits are one of the important fruits, produce all over the world. These include orange, Mausami and sweet orange (Dhillon et al., 2004). Nagpur is one of the major producer of orange fruits in India. Pectin is the major component of primary cell wall of all citrus fruits. Pectin is a polysaccharide which have important nutritional and gelleting properties in foods (Mohnen, 2008). Pectinolytic enzymes can be produced in large amount by microorganisms, using citrus peel as a substrate because it contains considerable quantity of pectin. It works as inducer for the synthesis of pectinolytic enzymes by microbial systems (Dhillon et al., 2004). These enzymes have the ability to degrade and chemically modify pectin (Zhang, 2006). Pectinases are commonly employed in juice, textile, paper and pulp industries. These enzymes catalyzed the conversion of complex polysaccharides into simpler molecules like galacturonic acids (Kashyap et al., 2000; Giese et al., 2008). These have wide industrial applications like oil extraction, tea extraction, juice clarification and waste water treatment (Hoondal et al., 2002; Botella et al., 2007; Mohnen, 2008). Microorganisms have various advantages and can be used for enzymes production at higher level. Pectinolytic enzymes have great biotechnological potential and can be employed in many important industrial processes (Tewari et al., 2005; Zhong and Cen, 2005). Aspergillus belongs to ascomycota group of fungi, genus Aspergillus. It is an opportunistically infectious microbe to human being and well adapted to environmental changes (Samson et al., 2001;
Baker, 2006). The current study was designed for the optimization and production of pectinase by Aspergillus sp. and then its characterization after partial purification.

\section{Material and Methods:}

Substrate preparation Orange peel was used as substrate. It was sliced, air dried and meshed with $40 \mathrm{~mm}$ mesh. Fermentative organism and sporulation medium Pure culture of A. niger, A. flavus., A. oryzae and A. fumigates were used. It were maintained on potato dextrose agar (PDA) slants which were inoculated at $30 \hat{\mathrm{A}}^{\circ} \mathrm{C}$ for 120 hours and stored at $4 \hat{\mathrm{A}}^{\circ} \mathrm{C}$ for further use(Motwani et al 2012). Numbers of spores were adjusted at 107-108 spores/mL microscope (Kolmer et al., 1951). Screening of fungal isolates for pectinolytic activity The fungal isolates were assayed for pectinase activity using pectin containing agar medium. Culture plates with pectin-containing agarose were inoculated with each isolate and incubated for 3-5 days at $31 \hat{\mathrm{A}}^{\circ} \mathrm{C}$. Isolates were replicated 2 to 3 times and tests were performed twice. After incubation, plates were stained with aqueous $0.05 \%$ ruthenium red solution for $1 \mathrm{~h}$ and rinsed with deionised water. Cultures expressing pectinase activity exhibited a clear zone around the margins of the colony. Solid state fermentation All experimental treatments were performed in triplicate flasks containing 5 $g$ substrate moistened with mineral salts solution. Flasks were plugged with cotton and growth medium was autoclaved at standard conditions. $2 \mathrm{~mL}$ of inoculum was added under aseptic conditions in autoclaved flasks. These flasks were then placed at $28 \hat{\mathrm{A}}^{\circ} \mathrm{C}$ temperature 
for specific time period. Enzyme harvesting Enzyme was harvested from growth media by sample contact method as described by Krishna and Chandrasekaran (1996). Harvested crude enzyme was stored at $4 \hat{\mathrm{A}}^{\circ} \mathrm{C}$ before performing enzyme assay. Enzyme characterization Pectinase was characterized for $\mathrm{pH}$ and temperature to increase its activity. Tris $\mathrm{HCl}$ buffer $(50 \mathrm{mM})$ was used to adjust the $\mathrm{pH}$. of the assay mixture. Enzyme assay was performed at different temperatures for temperature optimization. Partial purification byAmmonium sulphate precipitation Ammonium sulphate is water soluble ionic compound, maintain high ionic strength and precipitate out proteins by salting out. At high ionic strength, salt may remove water of hydration from proteins and reduce solubility, hence proteins were coagulated. Various concentrations of ammonium sulfate were used to obtained maximum precipitation and purification (Motwani et al 2013). Analytical methods Pectinase assay This study focused on the assay of pectinase enzyme for the most active fungal isolate. Pectinase assay was performed following the procedure of Miller, with some modification. Briefly, a reaction mixture composed of $0.2 \mathrm{ml}$ of crude enzyme solution, plus $1.8 \mathrm{ml}$ of $1.0 \%$ $(\mathrm{w} / \mathrm{v})$ citrus pectin in $50 \mathrm{mM}$ sodium acetate buffer ( $\mathrm{pH}$ 5.0) was incubated at $37 \hat{\mathrm{A}}^{\circ} \mathrm{C}$ in a shaker water bath for $30 \mathrm{~min}$. The reaction was terminated by adding $3 \mathrm{ml}$ of DNS reagent. The color was then developed by boiling the mixture for $5 \mathrm{~min}$. Optical densities of samples were measured at $575 \mathrm{~nm}$ against a blank containing the reaction mixture minus the crude enzyme. Results were then compared to controls inoculated with an inactive pectinolytic fungal isolate. Results were interpreted in terms of enzyme activity in which one unit of enzyme activity (U) was defined as the mount of enzyme releasing one $\hat{\mathrm{I}}^{1 / 4} \mathrm{~mol}$ reducing groups (D â $€^{\prime \prime}$ galacturonic acid) per min under these assay conditions. Protein estimation Protein was determined with a Folin-phenol reagent using Bovine Serum Albumin (BSA) as the protein standard(Lowry et al .,1951). Specific activity It is defined as number of units of enzyme activity per $\mathrm{mg}$ of protein. Pectinase purification Ammonium sulfate was used for the partial purification of crude pectinase; it precipitate protein by salting out process. Maximum protein was purified at $60 \%$ of ammonium sulfate, observed from enzyme activity.

\section{Result and Discussion:}

Microbes are the best source to obtain the important enzymes for human needs (Shafique et al., 2009). Enzymes synthesis by microorganisms is affected mainly by substrate, size of substrate particles, surface area of substrate, oxygen utilization, water \%, humidity, fermentation temperature, period of incubation and carbon dioxide removal (Jacob and Prema, 2008; Palaniyappan et al., 2009). Pectinases are among the most important industrial enzymes. The biotechnological potential of pectinolytic enzymes from microorganisms has drawn a great deal of attention from various researchers worldwide as likely biological catalysts in a variety of industrial processes.( Kashyap D.R et al.2000) In the current investigation, maximum pectinase activity was observed after $96 \mathrm{~h}$ of incubation (Figure 1). With the increase in incubation period, production of enzyme decrease due to accumulation of waste material and unavailability of nutrients. Pectinase has maximum activity in the range of $\mathrm{pH} 4.5-5.0$ of the growth media, indicating that pectinase produced by fungal strains are acidic in nature (Figure 2). Presence of $60 \%$ water contents other than inoculums is the most suitable for both, fungal growth as well as pectinase secretion. Similarly, $35 \hat{\mathrm{A}}^{\circ} \mathrm{C}-40 \hat{\mathrm{A}}^{\circ} \mathrm{C}$ is the most suitable temperature for the growth and production of pectinase by fungal strains (Figure 3). A. niger is a mesophilic fungi, growing well in moderate conditions and temperature.

Table 1: Partial purification of Pectinase by Ammonium sulfate precipitation from Aspergillus niger

\begin{tabular}{|l|c|c|c|c|}
\hline $\begin{array}{l}\text { Source of } \\
\text { Precipitation }\end{array}$ & $\begin{array}{l}\text { Enzyme Activity } \\
\text { in U/g }\end{array}$ & $\begin{array}{l}\text { Protein } \\
\text { Concentration }(\mathrm{mg} / \mathrm{ml})\end{array}$ & $\begin{array}{l}\text { Specific Activity } \\
\text { in U/mg }\end{array}$ & $\begin{array}{l}\text { Fold of } \\
\text { Purification }\end{array}$ \\
\hline Crude Enzyme & 528 & 200 & 2.64 & \multirow{2}{*}{5.65} \\
\hline $\begin{array}{l}\text { Ammonium salt } \\
\text { Fraction }\end{array}$ & 896 & 60 & 14.93 & \\
\hline
\end{tabular}

Table 2: Partial purification of Pectinase by Ammonium sulfate precipitation from Aspergillus flavus

\begin{tabular}{|l|c|c|c|c|}
\hline $\begin{array}{l}\text { Source of } \\
\text { Precipitation }\end{array}$ & $\begin{array}{l}\text { Enzyme Activity } \\
\text { in U/g }\end{array}$ & $\begin{array}{l}\text { Protein } \\
\text { Concentration }(\mathrm{mg} / \mathrm{ml})\end{array}$ & $\begin{array}{l}\text { Specific Activity } \\
\text { in U/mg }\end{array}$ & $\begin{array}{l}\text { Fold of } \\
\text { Purification }\end{array}$ \\
\hline Crude Enzyme & 480 & 150 & 3.2 & \multirow{2}{*}{2.85} \\
\cline { 1 - 3 } $\begin{array}{l}\text { Ammonium salt } \\
\text { Fraction }\end{array}$ & 640 & 70 & 9.14 & \\
\hline
\end{tabular}


Table 3: Partial purification of Pectinase by Ammonium sulfate precipitation forom Aspergillus oryzae

\begin{tabular}{|l|c|c|c|c|}
\hline $\begin{array}{l}\text { Source of } \\
\text { Precipitation }\end{array}$ & $\begin{array}{l}\text { Enzyme Activity } \\
\text { in U/g }\end{array}$ & $\begin{array}{l}\text { Protein } \\
\text { Concentration }(\mathrm{mg} / \mathrm{ml})\end{array}$ & $\begin{array}{l}\text { Specific Activity } \\
\text { in U/mg }\end{array}$ & $\begin{array}{l}\text { Fold of } \\
\text { Purification }\end{array}$ \\
\hline Crude Enzyme & 496 & 220 & 2.25 & \multirow{2}{*}{4} \\
\cline { 1 - 3 } $\begin{array}{l}\text { Ammonium salt } \\
\text { Fraction }\end{array}$ & 720 & 80 & 9 & \\
\end{tabular}

Table 4: Partial purification of Pectinase by Ammonium sulfate precipitation from Aspergillus fumigatus

\begin{tabular}{|l|c|c|c|c|}
\hline $\begin{array}{l}\text { Source of } \\
\text { Precipitation }\end{array}$ & $\begin{array}{l}\text { Enzyme Activity } \\
\text { in U/g }\end{array}$ & $\begin{array}{l}\text { Protein } \\
\text { Concentration }(\mathrm{mg} / \mathrm{ml})\end{array}$ & $\begin{array}{l}\text { Specific Activity } \\
\text { in U/mg }\end{array}$ & $\begin{array}{l}\text { Fold of } \\
\text { Purification }\end{array}$ \\
\hline Crude Enzyme & 464 & 200 & 2.32 & \multirow{2}{*}{4.46} \\
\cline { 1 - 1 } $\begin{array}{l}\text { Ammonium salt } \\
\text { Fraction }\end{array}$ & 704 & 68 & 10.35 & \\
\hline
\end{tabular}

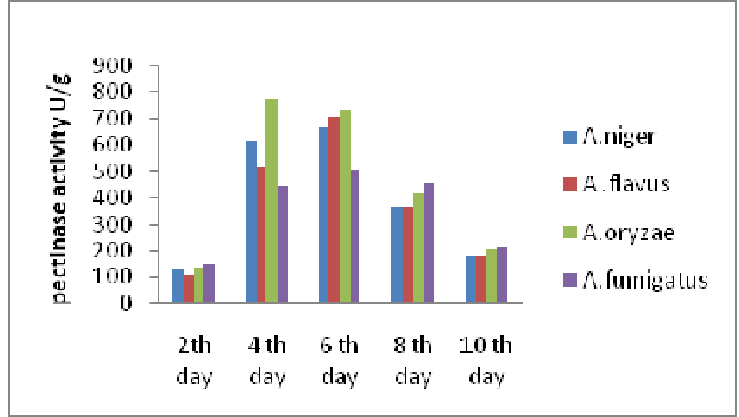

Figure 1 Effect of incubation period on pectinase production.

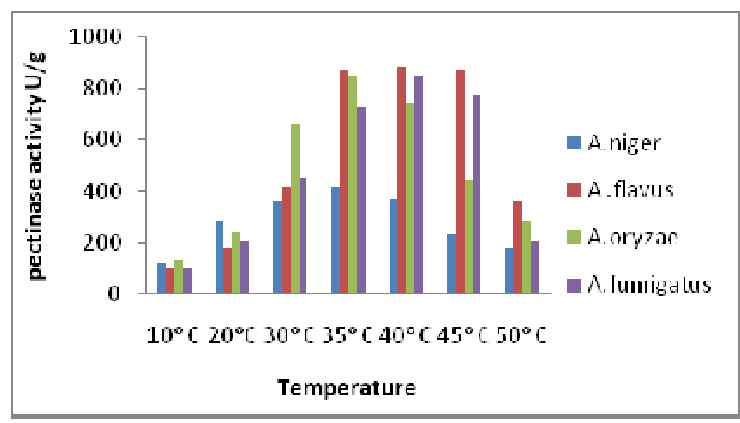

Figure 2 Effect of temperature on pectinase production.

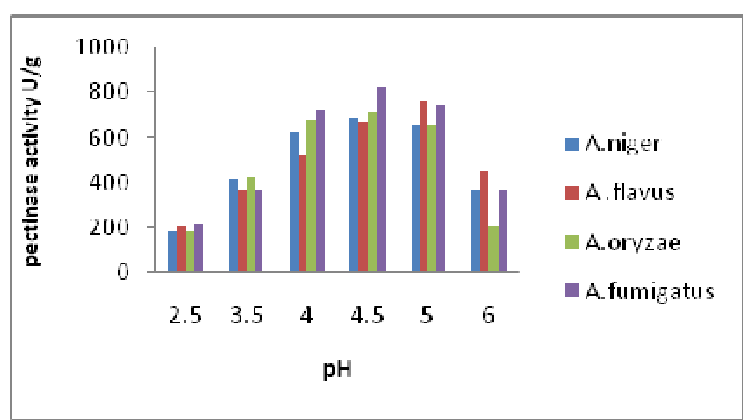

Figure 3 Effect of $\mathrm{pH}$ on pectinase production

\section{Conclusion:}

From the current study, it can be concluded that Aspergillus sp. can be a good source of pectinase. Supplementation of additional carbon and nitrogen are necessary for good enzymatic yield. In order to achieve further active pectinase further sophisticated purification techniques should be followed.

\section{Reference:}

Baker SE (2006). Aspergillus niger genomics:Past,present and into the future. Med.Mycol. 44:17-21.

Botella C, Diaz A, Deory I, Webb W, Blandino A (2007). Xylanase and pectinase production by Aspergillus awamori on grape pomace in solid state fermentation. Process Biochem. 42:98101.

Dhillon S, Gill SR, Gill SS, Singh M (2004). Studies on the utilization of citrus peel for pectinase production using fungus Aspergillus niger. Int. J. Environ. Stud. 61(2):199-210.

Giese EC, Dekker RFH, Barbosa AM (2008). Orange bagasse as a substrate for the production of pectinase and laccase by Botryosphaeria rhodina MAMB-05, in submerged and solid state fermentation. Biol. Res. 3(2):335-345.

Hoondal G, Tiwari R, Dahiya N, Beg Q (2002). Microbial alkaline pectinases and their industrial applications: a review. Appl. Microbiol. Biotechnol. 59:4-5.

Jacob N, Prema P (2008). Novel process for the simultaneous extraction and degumming of banana fibers under solid-state cultivation. Braz. J. Microbiol. 39(1):115-121.

Kashyap DR, Chandra S, Kaul A, Tewari R (2000). Production, purification and characterization of pectinase from a Bacillus sp. DT7. World J. Microbiol. Biotechnol. 16:277282.

Kolmer JA, Spaulding EH, Robinson HW (1951). Approved laboratory technics, p. 415. 5th ed. Appleton-Century-Crofts Inc., New York

Krishna C, Chandrasekaran M (1996). Banana waste as substrate for $\hat{\mathrm{I}} \pm$-amylase production by Bacillus subtilis (CBTK 106) under solid-state 
fermentation Appl. Microbiol. Biotechnol. 46(2): 106-111.

Lowry, O.H., N.G. Rosebrough, A.L. Farr and R.J.Randall. Protein measurement with the folin phenol reagent J. Bio. Chem., 1951;193: 265-275.

Miller GL. Use of dinitrosalicylic acid reagent for determination of reducing sugars. Anal Chem 1959;31:426-8.

Mohnen D (2008). Pectin structure and biosynthesis. Curr. Opin. Plant Biol. 11(3):266277.

Motwani, D. R., Meshram, V. G., Jambhulkar, V. S. and Ingle, A. A, (2012). Pectinase production in solid state fermentation by Aspergillus flavus using orange peel as substrate.Bionano frontier Vol.5pp 236-239

Motwani, D. R., Meshram, V. G. and Jambhulkar, V. S. (2013). Partial characterization of pectinase produced by Aspergillus niger grown on wheat bran .IJSER,Vol4,Issue 12 pp345-365

Palaniyappan M, Vijayagopal V, Viswanathan $\mathbf{R}$, Viruthagiri $\mathbf{T}$ (2009). Screening of natural substrates and optimization of operating variables on the production of pectinase by submerged fermentation using Aspergillus niger MTCC 281. Afr. J. Biotechnol. 8(4):682-686.

Tewari R, Tewari RP, Hoondal GS (2005). Microbial Pectinases. Methods in Biotechnol. 17:191-208

Samson RA, Houbraken J, Summerbell RC, Flannigan B, Miller JD (2001). Common and important species of fungi and actinomycetes in indoor environments. In: Microogranisms in Home and Indoor Work Environments. New York: Taylor \& Francis, pp. 287-292.

Shafique S, Bajwa $R$, Shafique $S$ (2009). Screening of Aspergillus niger and A. flavus strains for extra cellular alpha-amylase activity. Pak. J. Bot. 41(2):897-905..

Zhang J (2006). Biochemical Study and Technical Applications of Fungal Pectinase. Acta Universitatis Upsaliensis Digital Comprehensive Summaries of Uppsala Dissertations from the Faculty of Science and Technology. pp. 137-147.

Zhong WH, Cen PL (2005). Pectinase production by Aspergillus niger P-6021 on Citrus Changshan-huyou peel in slurry-state fermentation. Chin. J. Chem. Eng. 13(4):510515 